\title{
UNDERSTANDING ENGLISH TEXTS FOR NON-ENGLISH STUDENTS: READING HABITS AND READING PREFERENCES IN AZ-ZAINIYAH NURUL JADID
}

\author{
MOCHLIS EKOWIJAYANTO \\ Universitas Nurul Jadid Paiton Probolinggo \\ mochliseko@gmail.com \\ YAYUK ASTUTIK \\ Universitas Nurul Jadid Paiton Probolinggo \\ yayuka0698@gmail.com \\ NUR KHOMARIYAH \\ Universitas Nurul Jadid Paiton Probolinggo \\ missrieya24@gmail.com
}

\begin{abstract}
The role of students in Indonesia is needed, especially their ideas and opinions to develop this country. The quality of human resources is certainly very relevant to students' interest in reading. Reading habits are not only related to the teaching and learning process, but also can shape the personality of an individual by living the reading results. The research aims to study the process of reading habits and reading preferences favored by students. The research method used was a descriptive survey involving 45 students of non-English students in Az-Zainiyah Nurul Jadid. In obtaining data to find out the problems faced by students in understanding English reading texts, a questionnaire was used relating to reading habits and reading preferences. The findings from this study are expected to be used as an evaluation material that reading skills also need to be introduced further to students so that they can use them in the reading process.
\end{abstract}

Keywords: English text, reading habits, reading preferences

\section{INTRODUCTION}

The position of English in the industrial era 4.0 is now getting stronger. This is proven by making English the official language of business between ASEAN countries by the blueprint of the ASEAN Economy Community (AEC). By making English the language of communication between ASEAN countries then as a citizen of a member of ASEAN, mastery of English is an absolute matter. People who have good English skills will have greater opportunities to get jobs, not only domestically but also abroad. Some countries in ASEAN, English lessons are a compulsory part of the primary to secondary school curriculum. Depending on the quality of their school and teacher training in English, their devotion to learning and to improve their English skills and their level of confidence, teachers may also try to convince doubts that arise about how well they can teach English. (Waterworth, 2016).

According to UNESCO data, reading interest Indonesian people is very alarming, itjust $0.001 \%$. It means that out of 1,000 Indonesians, only 1 person is avid reader. Interest in reading Indonesia is ranked 60, only one level above Botswana, one of the countries in Africa which is ranked 61. Therefore, increasing literacy is one of the challenges in encouraging a willingness to know more knowledge, information and knowledge (Rina A., 2019).

The government then requires each student to learn English at all levels of the school which is implemented in the national curriculum, which teaches English from elementary to tertiary levels in Indonesia includes four language skills, namely speaking skills, listening skills, reading skills and writing skills. The teaching of these four skills should be integrated in the teaching and learning process that occurs in the classroom so that students can develop their abilities simultaneously. Listening skills (listening) and reading skills (reading) are called receptive skills where a person does not need to produce language, they accept and understand the language. This skill is commonly called passive skill. While speaking and writing skills are called productive skills where people use the language they have learned and produce messages 
in the form of oral or written texts so that others understand(Gunantar, 2016).

Reading as one of the skills that must be developed in learning English cannot be separated from other skills because the ability of students to one skill will support the ability to master other skills. Reading is an extremely complex process that no one can explain satisfactorily (Ngabut, 2015). Without mastering reading skills, one's language skills will not develop. Having the ability to read is needed by a student because with this ability they will be able to improve their English language skills. By reading, students will certainly be able to increase their vocabulary in their English which will ultimately help to develop their writing and speaking skills. In consequence, the comprehension skill to find details information, references, and guessing word meaning play a great role in determining the readers' overall understanding of the text being read (Yusuf, Yusuf, Yusuf, \& Nadya, 2017).

It seems, it is undeniable that in the process of learning English, there are still many students who have difficulty in developing their reading skills which causes a low ability to understand an English text. Several things cause the low reading ability of students so far. The lack of reading practice is the main cause of the low ability to read. The students usually fail the reading test because of lack of reading materials in English.Therefore, students who learn English in context as a foreign language may lack English proficiency when they read EFL texts, which means that they will face greater difficulties in reading comprehension later(Sunggingwati \& Nguyen, 2013). Another cause is the habit of students who currently prefer to do other things besides reading, for example playing games, watching television, and hanging out with friends. Besides reading is also considered as a boring activity. The students find comprehension is the most difficult aspect. Students today prefer to socialize through various social media rather than taking the time to read(Mabruroh, 2020)

Reading skills are an important factor that determines the success of a student in mastering English. The ability to read a person is strongly influenced by reading habits. Reading habits are voluntary activities because reading is a personal need. Reading activities can be said to be a habit if someone is automatically stimulated to read. For example if reading is a habit, a student wants to take a course, there are several ways to develop it.. The student will realize that reading is highly enjoyable (Suhana \& Haryudin, 2017). So to strengthen students' reading comprehension it is very necessary to improve their reading habits. reading habits, reading preferences are also very helpful for students in mastering these skills. The benefits of reading habits are very great for students in learning English. By reading students can open new worlds and broaden their perspectives. Besides reading habits will also greatly help students to speak confidently. Getting used to reading as a routine activity will help students to understand various texts in English fluently and precisely. Besides that, having good reading habits will make someone smarter and improve analysis in understanding a text.

Reading may be regarded as a fundamental skill to be acquired by every learner and hence every effort should be directed towards its development from early life. Without the habit of reading, a child can grow up with various difficulties to be faced, most of which need to be worked out that require reading at any level (Chettri, 2013). In addition, there are also problems in the mindset of people who make them reluctant to make reading a habit. The mindset of reading only for hobbies is still often heard in our ears. This point of view is the reason someone does not want to read just because it is not his hobby. It is undeniable that reading is a key storehouse of knowledge that must be a condition for the progress of humanity in the future(Wening V. R, 2019).

This research was conducted to understand the importance of developing reading skills for students. One way to improve students' reading skills is to know their reading habits and reading preferences so far. By knowing the habits and preferences of students reading, it will be easier for an English lecturer to design teaching techniques for reading skills and be able to know various text models that will be given to students. Also, this research is expected to motivate English lecturers at Nurul Jadid University to develop their students' reading habits. 
In addition to being interested in knowing students' reading habits, this study was also conducted based on the experience researchers found during teaching English. Students have low understanding so that they often find difficulty answering questions related to reading texts. These difficulties are often caused by a lack of vocabulary in language English is owned so that in reading English-language texts they spend a lot of time opening dictionaries and searching for meanings of words they wanted to know.

\section{METHOD}

To be able to reveal the problems that exist in this study, the qualitative descriptive analysis method is used. The qualitative description analysis method is used as a problem solving procedure that is examined by describing or describing the state of the research object at the time the research is conducted, based on the facts that appear as they are. The object of research that will be described is the reading habits and matters relating to the reading interest of non-English program students. Data about students' reading habits will be obtained through a questionnaire distributed to students who become the sample in this study. The results of the student questionnaire collected will then be described or explained to get an overview of the reading habits of non-English program students.

The stages carried out in this study are as follows; 1) Create a questionnaire to determine students' reading habits and reading preferences. 2) provide questionnaires about reading habits and reading preferences to students who are used as research samples. 3) After the data is collected, each student's answer will be calculated according to the available preferences. 4) Explain the results of the student questionnaire. The research was carried out for six (6) months, starting in January until June 2021. The place for this research was the Az-Zainiyahcollague of NurulJadid.

The population in this study were non-English students who stay in Az-Zainiyahcollague of NurulJadid. The sample in this study was the Senior High School of NurulJadidwhich amounted to 45 students.

The data in this study were obtained through an instrument in the form of a questionnaire is to use a semi-open-ended model to find out the reading habits and reading preferences of students. The semi-open-ended questionnaire model that will be used in this study uses questions for which some possible answers have been provided by the researcher. Also, each item from the questionnaire will be accompanied by their reasons for choosing certain answers. So from their answers it is hoped that the data from this questionnaire will reflect the real conditions related to student reading habits.

Data analysis techniques in this study used descriptive analysis to analyze the data obtained through a questionnaire given to students who were sampled in this study. The number of questions on the questionnaire is 20. Data collected through this questionnaire will be tabulated based on the preferences provided or other answers given by students. The percentage of each choice will be calculated and then the percentage will be described per item by the researcher. Besides, researchers will describe the reasons given by students for each item questionnaire.

\section{FINDINGS AND DISCUSSION}

This study uses a questionnaire as an instrument to obtain the data desired by researchers. This questionnaire is in the form of semi-open-ended questionnaire. There are 20 number of questions where each question has been given certain preferences but still allowed students to give other preferences. Besides that students who become the sample of this research must give reasons for each choice they give. Even though there are 5 numbers from the questionnaire that do not require a reason.

The questions contained in the questionnaire were made based on the purpose of the study which is to find out reading habits, know the reading skills used by students and to find 
out the obstacles encountered during the reading process. Based on these objectives, several questions serve to find out about reading habits, also some questions aim to find out about reading skills as well as some questions that are made to find out the obstacles faced by students who are the sample of this study. Questions number 1 to number 10 are questions created to find out the reading habits of students. While questions number 11 to 20 are questions that serve to find out the reading skills and obstacles faced by students.

The discussion will show the type of information you want to know as well as the results of the questionnaire shown by the table for each number. Researchers will discuss questions related to reading habits.

Table.1. Student activities during leisure time.

Leisure Activities $\quad$ Number ofrespondents $\quad$ Percentage

\begin{tabular}{lcc}
\hline Reading book & 9 & $20 \%$ \\
Watching television & 5 & $11 \%$ \\
Playing games & 11 & $24 \%$ \\
Gather with friends & 11 & $24 \%$ \\
Others & 9 & $20 \%$ \\
\hline
\end{tabular}

Based on table 1, it can be seen that students spend most of their free time playing games (24\%) and hanging out with friends (24\%). Reading books is only chosen by around $20 \%$ of students, and watching television is the activity most rarely performed by students in their spare time, this is because most Senior High School of Nurul Jadid students live in boarding schools that certainly do not have television. Other activities (20\%) chosen by students besides the preferences provided are watching anime, listening to lectures, sleeping, reading articles and reading novels, and organizing.

The reasons given by respondents for game play activities (24\%) most of the students consider that playing games is their hobby, also they think that playing games is much easier to understand, more exciting and can relieve stress after facing a heavy lecture. Meanwhile the reasons given by students for those who choose to gather with friends are generally because they are far more happy when gathering with friends. Students who choose to read books as leisure activities have the reason that by reading books they can add insight, knowledge, get references for academic assignments and those who think that reading a book is a fun activity.

In addition, it is still related to reading habits, the following is to find out the level of their liking towards reading. For this question as shown in table 2 , it can be seen that around $76 \%$ of respondents stated that they like reading with reason to add insight and gain more knowledge about various Thing. There are about $11 \%$ of respondents who stated that they did not like to read. As for the reasons they gave for their dislike of reading, reading made them sleepy and boring. 
VOL. 03 NO. 01, JUNE 2021

Table. 2. The level of interest in reading.

\begin{tabular}{lccc}
\hline $\begin{array}{l}\text { Favorite level for } \\
\text { reading }\end{array}$ & & Number ofrespondents & Percentage \\
\hline Very & 2 & & $4 \%$ \\
LikeLike & & 35 & $76 \%$ \\
Dislike Very & 5 & & $11 \%$ \\
Dislike & 0 & $0 \%$ \\
Others & 4 & $9 \%$ \\
\hline
\end{tabular}

Opinions about the importance of reading, on questions about whether they think reading is important, the results of the questionnaire as shown in table 3.

Table. 3. Opinions about the importance of reading

\begin{tabular}{lccc}
\hline $\begin{array}{l}\text { Opinions about the } \\
\text { importance of } \\
\text { reading }\end{array}$ & Number ofrespondents & Percentage \\
\hline Very & 30 & $67 \%$ \\
ImportantImportant & 15 & $33 \%$ \\
Not too Important & 0 & & $0 \%$ \\
Not ImportantOthers & 0 & & $0 \%$ \\
& 0 & & $0 \%$ \\
\hline
\end{tabular}

There is an interesting fact that looks at the results of the questionnaire to the question whether you think reading is important. Table 3 clearly shows that about $67 \%$ of respondents think that reading is very important and about 33\% of respondents think that reading is important. None of the students thought that reading was not very important and not important. This states that although most students prefer other activities besides reading as an activity in their free time but they have an awareness that reading is very important. The reason given by students is that reading is very important because by reading they can add knowledge, get a lot of information, broaden their horizons, and reading is important for their future.

Concerning reading time, the following is the time spent in a day reading. Based on table 4 , it is known that most students (52\%) provide other options including more than 4 hours, less than 1 hour and not specified. There are only about $17 \%$ of students who read for 1 hour a day and around $15 \%$ spend 2 hours reading. Only about $7 \%$ of respondents spend 4 hours reading.

Table. 4. The time spent reading in a day

\begin{tabular}{lccc}
\hline $\begin{array}{l}\text { Time to read } \\
\text { per day }\end{array}$ & & Number ofrespondents & Percentage \\
\hline 1 hour & 8 & $17 \%$ \\
2 hours & 7 & $15 \%$ \\
3 hours & 4 & & $9 \%$ \\
4 hours & 3 & 24 & $7 \%$ \\
Others & & & $52 \%$ \\
\hline
\end{tabular}

In terms of the type of book that the respondent most likes to read can be seen in the following table 5 below. 
Table. 5. The most read book genre

\begin{tabular}{cccc}
\hline $\begin{array}{l}\text { The most read book } \\
\text { genre }\end{array}$ & Number ofrespondents & Percentage \\
\hline Fiction & & 12 & $27 \%$ \\
Textbook & 3 & & $7 \%$ \\
Magazine & 4 & & $9 \%$ \\
Biography & 8 & 18 & $18 \%$ \\
Others & & & $40 \%$ \\
\hline
\end{tabular}

Based on table 5 , it is known that about $40 \%$ of students choose other options besides those already provided. Their preferences vary from the Koran, articles, newspapers, articles related to computer programs, and comics. The highest choice is fiction where as many as $27 \%$ of students choose fiction as the reading they most like to read. As for the reasons for choosing fiction because they think that fiction is far more interesting than other options. While the lowest is textbook, only $7 \%$ of respondents choose textbook as the type of book they like to read the most.

From the type of introductory language of a book, it is very clear that around $89 \%$ of respondents choose to read books in Indonesian compared to English (7\%) and Korean (0\%) and Japanese $(0 \%)$. The main reason why they much prefer to read books with an introduction to Indonesian is because the language is the mother tongue so it is much easier to understand. The reason students choose to read books in English is that they like reading novels in English because most of the articles are in English. This can be seen in table 6 .

Table. 6. Types of language of instruction in books

\begin{tabular}{lccc}
\hline $\begin{array}{l}\text { Types of language of } \\
\text { instruction in books }\end{array}$ & Number ofrespondents & Percentage \\
\hline Indonesian & 40 & $89 \%$ \\
Korean & 0 & & $0 \%$ \\
Japan & 0 & & $0 \%$ \\
English & 3 & $7 \%$ \\
Lainnya & 2 & $4 \%$ \\
\hline
\end{tabular}

In matters that are still related to reading habits, the question of how often students choose to read English books can be seen in the results in table 7 .

Table. 7. How often to read books in English

\begin{tabular}{lccc}
\hline $\begin{array}{l}\text { How often to read } \\
\text { books in English }\end{array}$ & & Number ofrespondents & Percentage \\
\hline Very & 2 & & $4 \%$ \\
oftenOften & 3 & 36 & $7 \%$ \\
Rarely & & & $80 \%$ \\
Ever & 3 & & $7 \%$ \\
Others & 1 & & $2 \%$ \\
\hline
\end{tabular}

The number of students who choose to rarely read English books is 36 people out of a total of 45 students. Only about $7 \%$ often read English books. The reason why $80 \%$ of students rarely read English language books is because they do not understand, difficulty interpreting 
what is read and lack of vocabulary.

The following discussion about the questions used to find out the reading skills used by students in the reading process. Regarding the importance of reading skills in the reading process, the results of student questionnaires can be seen in table 8 .

Table. 8. How important are reading skills

\begin{tabular}{lccc}
\hline $\begin{array}{l}\text { How important are } \\
\text { reading skills }\end{array}$ & Number ofrespondents & Percentage \\
\hline Very & 26 & $57 \%$ \\
importantImportant & & 19 & $41 \%$ \\
Not important & 1 & & $2 \%$ \\
Very & 0 & & $0 \%$ \\
unimportantOthers & 0 & & $0 \%$ \\
\hline
\end{tabular}

From the data above, around $57 \%$ of respondents think that reading skills are very important in the reading process to understand the text or book being read. The second highest number is around $41 \%$ of respondents think that reading skills are important to use during the reading process. Only about $2 \%$ think that reading skills are not important in the reading process. The reason students think that reading skills are very important and / or important because by using reading skills they can understand the contents of reading, can affect the speed of reading and to avoid meaning errors in reading.

The importance of knowledge about reading skills is needed for every reader in understanding the contents of the text to be read. The following is a description of the questionnaire results about where they learned about reading skills (table 9).

Table. 9. Knowledge of reading skills is obtained

\begin{tabular}{cccc}
\hline $\begin{array}{l}\text { Knowledge of reading } \\
\text { skills is obtained }\end{array}$ & Number ofrespondents & Percentage \\
\hline Individual & 6 & 16 & $36 \%$ \\
Textbook & & 18 & $13 \%$ \\
Class & 5 & & $40 \%$ \\
Online & 0 & $11 \%$ \\
Others & & $0 \%$ \\
\hline
\end{tabular}

Based on table 8 it is known that $40 \%$ of respondents know about reading skills through the class which means that knowledge about it is conveyed by their teacher or lecturer. While around $36 \%$ of respondents know about reading skills by self-learning through personal experience.

The questions below are related to reading skills that are often used by students when reading Indonesian and English texts. Please note that in these 2 questions students can choose more than one choice related to reading skills that they often use when reading. The following tables 10 and 11 explain the results of the questionnaire about reading skills.

Tabel. 10 Reading skills are often used in reading Indonesian texts

Reading skills are often used in reading Indonesian texts

Number ofrespondents

Percentage 


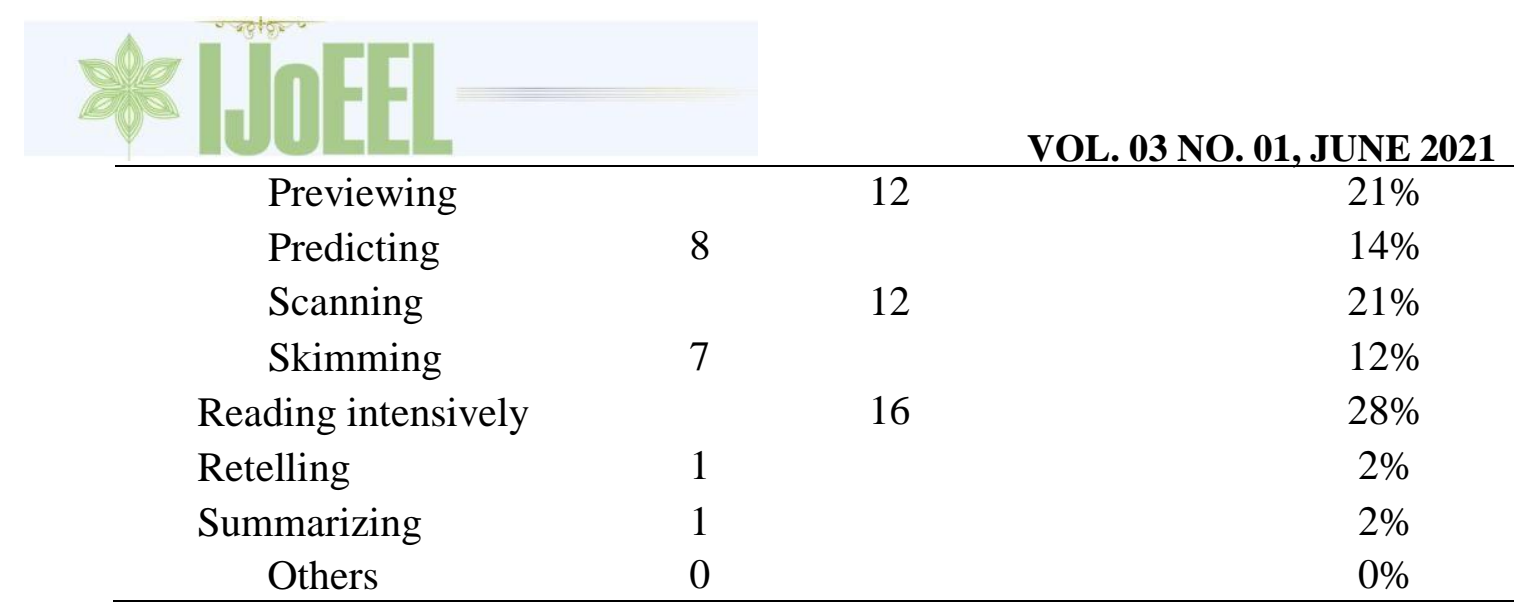

Tabel. 11 Reading skills are often used in reading English texts

\begin{tabular}{cccc}
\hline $\begin{array}{l}\text { Reading skills are often used } \\
\text { in reading English texts }\end{array}$ & Number ofrespondents & Percentage \\
\hline Previewing & 8 & & $15 \%$ \\
Predicting & & 10 & $19 \%$ \\
Scanning & 7 & & $13 \%$ \\
Skimming & 8 & & $15 \%$ \\
Reading intensively & & 14 & $27 \%$ \\
Retelling & 1 & & $2 \%$ \\
Summarizing & 3 & & $6 \%$ \\
Others & 1 & & $2 \%$ \\
\hline
\end{tabular}

The results of the questionnaire showed that for both texts, Indonesian and English, respondents chose intensive reading as the reading skill they most often used in reading, 28\% for Indonesian texts and 27\% for English texts. As for previewing (21\%) and scanning (21\%) are skills that are also often used by students in the process of reading English texts. Whereas predicting is the second skill that is often used by respondents in reading English texts. Seeing the similarity of using the same skills for Indonesian and English texts, it can be concluded that students tend to use the same method in reading texts even though they use different languages. The following discussion relates to obstacles or difficulties that are generally faced by respondents in the reading process. Table 12 and table 13 will show the results of the questionnaire related to the difficulties often faced in understanding Indonesian and English texts.

Tabel. 12. Difficulties that are often faced in understanding Indonesian texts

Difficulties that are often
faced in understanding
Indonesian texts

\begin{tabular}{lccc} 
Vocabulary & 11 & $24 \%$ \\
The main idea of each paragraph & 11 & $24 \%$ \\
Make conclusions & 6 & & $13 \%$ \\
Relations between paragraphs & & 10 & $22 \%$ \\
The others & 7 & & $16 \%$ \\
\hline
\end{tabular}




\section{Difficulties that are often \\ Difficulties that are often
faced in understanding English texts}

Vocabulary

Pronunciation for reading aloud

Main ideas

Relations between paragraphs

The others
Number ofrespondents

Percentage

The most common difficulty encountered by respondents both in reading Indonesian and English texts is vocabulary although the percentage is much different but they both occupy the same position in terms of the difficulties that are most often encountered. Vocabulary is an obstacle for $24 \%$ of respondents in reading Indonesian texts. This amount is equal to the number of respondents who chose constraints in determining the main idea of each paragraph. Meanwhile for English-language texts, around $76 \%$ of respondents choose vocabulary as the most common difficulty they face in reading texts. The second difficulty that is often encountered in reading English texts is the pronunciation constraints for reading aloud (11\%). Therefore, it can be concluded that even in reading Indonesian-language texts the students who were respondents in this study still faced problems in terms of vocabulary or vocabulary. This could be due to their low reading habits so that there were many vocabularies in our language that they were not understanding. Meanwhile the vocabulary problem is still the main problem of students in learning English. Finally, what will be discussed is related to the efforts made to overcome the problem when reading a text. This will be illustrated through table 14 .

Table 14. Efforts are made to overcome problems when reading a text

Efforts are made to overcome problems when reading a text
Number ofrespondents

\section{Percentage}

$\begin{array}{lccc}\text { Read more than once } & & 30 & 67 \% \\ \text { Make notes about the main ideas } & 2 & 4 \% \\ \text { Make a summary } & 6 & 13 \% \\ \text { Discuss reading results with friends } & 7 & 16 \% \\ \text { the other } & 0 & 0 \%\end{array}$

The most frequent effort made by respondents when having difficulty reading texts both Indonesian and English texts is reading more than once (67\%). In this way respondents felt they could better understand the contents of the reading they were reading. The second highest choice is discussing with friends about the text that has just been read, around 16\% of respondents choose the effort.Based on the results of the questionnaire it can be concluded that many things affect the reading ability of a student. Some of the things that cause low reading skills are poor reading habits, inadequate reading skills and other difficulties that are most often encountered by a student.

Senior High School of NurulJadid students think that reading is a very important activity in their lives. They also realize that there are many things they can get by reading, for example, adding their insights, adding new knowledge, and helping in their teaching and learning process on campus. However, this awareness is not accompanied by a pretty hard effort from students to 
help themselves. This is evidenced from the results of the questionnaire, students prefer playing games and hanging out with their friends rather than reading books in their spare time. Also, the time used by students to read in a day is generally less than 1 hour, although some people spend 4 hours reading. In conjunction with English lessons, students should read more Englishlanguage texts, although based on the results of the study respondents much prefer to read Indonesian-language texts rather than reading English-language texts.

Related to reading skills that are often used by respondents when reading Indonesian and English texts are intensive reading, predicting and previewing. Whereas concerning the obstacles faced by the respondents of this study most chose vocabulary as the obstacle that they most often encountered in the process of reading and rising was Indonesian and English texts.

The results achieved so far are researchers have made a questionnaire that will be given by students who are sampled in this study. This questionnaire as mentioned in chapter 3 is a semi open ended questionnaire where most of the possible answers have been provided by researchers but respondents are still allowed to give answers that are different from those provided. Besides, the researcher in most of the questionnaire questions gave a reasoning section in which students who became research samples could give reasons for their preferences.

\section{CONCLUSIONS}

Based on the results of the study it is known that non-English students of AzZainiyahNurulJadidwho were sampled in this study spent more of their free time playing games $(24 \%)$ and hanging out with friends (24\%). Only $20 \%$ of students read books in their free time. Although the majority of respondents namely $76 \%$ of students said they liked to read because by reading they could increase knowledge. Likewise students thought that reading was very important (63\%), but in reality they mostly only used their time less than one hour (52\%) read in a day.

Related to the reading skills used by students in the reading process it is known that students think that reading skills are very important in the reading process (57\%). Meanwhile the skills most often used by respondents for English-language texts are intensive reading (28\%), predicting (21\%), and scanning (21\%). This is almost similar to English texts where reading intensively $(27 \%)$ become the most commonly used skills. Then predicting (19\%) and previewing and skimming, each amounting to $15 \%$.

Regarding the obstacles faced by the respondents in understanding Indonesian language texts, it was found that vocabulary became the main obstacle in reading English texts, which amounted to $24 \%$ of students choosing that option. Recognizing the main idea of each paragraph is the second problem (24\%) that is often encountered by students. while for English-language texts $76 \%$ of students choose vocabulary as the most frequently encountered problem in the reading process. This eventually becomes the main obstacle for students mastering English. 


\section{REFERENCES}

Chettri, K. (2013). Reading Habits - An Overview. IOSR Journal Of Humanities And Social Science, 14(6), 13-17. https://doi.org/10.9790/0837-01461317

Gunantar, D. A. (2016). the Impact of English As an International Language on English Language Teaching in Indonesia. The Impact of English As an International Language on English Language Teaching in Indonesia, 10(2), 141-151. https://doi.org/10.15294/lc.v10i2.5621

Mabruroh, N. L. (2020). I Hate Reading” Revealing Academic Reading Difficulties of Indonesian Learners of English. Retrieved from https://repository.unej.ac.id/bitstream/handle/123456789/98159/Nuril Lailatul Mabruroh 150110101087.pdf?sequence $=1 \&$ isAllowed $=y$

Ngabut, M. N. (2015). Reading Theories and Reading Comprehension. Journal on English as a Foreign Language, 5(1), 25. https://doi.org/10.23971/jefl.v5i1.89

Rina A. (2019). Tingkat Baca Indonesia Masih Rendah. Retrieved from SINDONEWS website: https://ekbis.sindonews.com/berita/1444945/33/tingkat-baca-indonesia-masih-rendah-srimulyani-gencarkan-literasi

Suhana, A., \& Haryudin, A. (2017). the Effects of Reading Habit Towards Students' Reading Comprehension At Private Senior High Schoolin Purwakarta. ELTIN JOURNAL, Journal of English Language Teaching in Indonesia, 5(2), 57. https://doi.org/10.22460/eltin.v5i2.p57-70

Sunggingwati, D., \& Nguyen, H. T. M. (2013). Teachers' questioning in reading lessons: A case study in Indonesia. Electronic Journal of Foreign Language Teaching, 10(1), 80-95.

Waterworth, P. (2016). Teaching english in ASEAN: The voices of english teachers in ASEAN nations. Indonesian Journal of Applied Linguistics, 5(2), 154-166. https://doi.org/10.17509/ijal.v5i2.1340

Wening V. R. (2019). Reading Interest Problems in Indonesia. Retrieved from https://www.its.ac.id/news/en/2019/05/22/reading-interest-problems-in-indonesia-bookday-opinion/

Yusuf, Q., Yusuf, Y. Q., Yusuf, B., \& Nadya, A. (2017). Skimming and scanning techniques to assist EFL students in understanding English reading texts. Indonesian Research Journal in Education $\mid$ IRJE|, 1(December 2017), 43-57. 